\title{
Quality characteristics of low salted garlic Doenjang during fermentation
}

\author{
Kye-Man Cho ${ }^{1}$, Jae-Ran Kang ${ }^{2}$, Gyeong-Min Kim² ${ }^{2}$, Min-Jung Kang ${ }^{2}$, Chung-Eun Hwang ${ }^{1}$, \\ Young-Shim Jeong ${ }^{1}$, Jeong-Hwan Kim ${ }^{3}$, Chang-Kwon Lee ${ }^{4}$, Jung-Hye Shin ${ }^{2 *}$ \\ ${ }^{1}$ Department of Food Science, Gyeongnam National University of Science and Technology, Jinju 660-758, Korea \\ ${ }^{2}$ Namhae Garlic Research Institute, Namhae 668-812, Korea \\ ${ }^{3}$ Department of Food Technology, Institute of Agriculture and Life Science, Gyeongsang National University, Jinju 660-701, Korea \\ ${ }^{4}$ Mong-Go Foods Co., Ltd, Changwon 641-465, Korea
}

\section{저염 마늘된장의 숙성기간에 따른 품질특성}

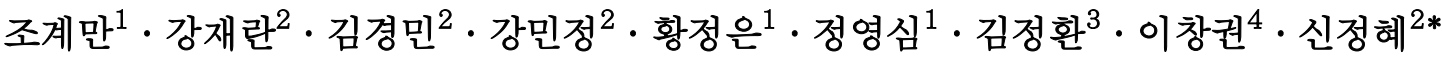 \\ ${ }^{1}$ 경남과학기술대학교 식품과학부, ${ }^{2}($ 재 $)$ 남해마늘연구소, \\ ${ }^{3}$ 경상대학교 식품공학과 - 농업생명과학연구원, ${ }^{4}$ 몽고식품(주)
}

\begin{abstract}
We investigated the changes in the quality characteristics of Doenjang with low salt contents $(6,8,10$, and $12 \%)$ and $10 \%$ garlic. The Doenjang was analyzed at an interval of a week during its fermentation for six weeks, at room temperature. Its $\mathrm{L}$ color gradually decreased, but its a and b colors did not change significantly. Its salinity increased by about $1 \%$ after six weeks. In contrast, immediately after its preparation, its pH was gradually decreased and its acidity was increased for the fermentation. The reducing sugar was significantly increased from 1.34 1.88 $\mathrm{g} / 100 \mathrm{~g}$ immediately after its preparation to $7.25 \sim 9.13 \mathrm{~g} / 100 \mathrm{~g}$ after six weeks, which was higher as the salt concentration decreased. The amino-type nitrogen doubled from $100 \sim 130 \mathrm{mg} \%$ at 0 week to $210 \sim 290 \mathrm{mg} \%$ at six weeks, which were lower with the higher salt concentrations. The growth curve of the Bacillus fermentation strains of Doenjang increased to two weeks but gradually decreased since, and the growth of the Bacillus was favorable for up to two weeks in the Doenjang with $10 \%$ and $12 \%$ salt added. Otherwise, the yeast was reduced rapidly during the early fermentation of the Doenjang, and slightly changed after three weeks of fermentation. The results of this study showed that the reducing sugar and amino-type nitrogen contents of the low-salt garlic Doenjang were higher with the lower salt dose, and the physicochemical quality of the 6\%-salt Doenjang was not significantly affected. Thus, we suggest that low-salt Doenjang can be manufactured with the addition of $6 \%$ salt and $\mathbf{1 0 \%}$ garlic.
\end{abstract}

Key words : low salt, soybean paste, Doenjang, quality characteristics

\section{서 론}

된장은 간장, 청국장 등과 함께 식생활에 광범위하게 이 용 및 섭취되어온 우리나라의 대표적인 콩 유래 발효식품 중 하나로 필수아미노산, 비타민, 유기산, 지방산 및 미네랄 등을 보충해주어 영양학적으로 우수한 식품으로 알려져

*Corresponding author. E-mail : whanbee@hanmail.net Phone : 82-55-860-8947, Fax : 82-55-860-8945
있으며 $(1,2)$, 그 수요 또한 장류 시장에서 상당 부분을 차지 하고 있다. 된장은 국내외 다수의 연구자들에 의해 항암 $(3,4)$, 항돌연변이(5), 항산화 $(6,7)$, 항콜레스테롤 $(8,9)$, 혈압 강하 $(10,11)$, 혈전용해 $(12,13)$ 및 면역증진(14)과 같은 기능 성이 보고되고 있다. 최근에는 된장의 기능성을 더 강화하 고, 풍미를 향상시키고자 표고버섯(15), 감귤, 녹차, 선인장 분말(16), 마(17), 유색 고구마(18) 첨가 된장 등 현대인의 기호에 따른 다양한 기능성 물질 및 식품을 첨가한 된장 제품들이 지속적으로 연구·개발되고 있다. 
된장은 발효할 때 부패를 예방하고 장시간 저장과 유통 을 용이하게 하기 위하여 통상적으로 $10 \sim 14 \%$ 의 식염을 첨가하는데, 경우에 따라서는 $20 \%$ 의 식염이 첨가되기도 한다(19). 식염은 된장의 원료 중에서 미생물의 생육에 가장 큰 영향을 주지만 과다한 식염의 사용은 강한 짠맛으로 품질에 악영향을 주며 고혈압, 뇌졸중과 같은 성인병을 유 발하는 등의 역기능을 유발하는 원인이 되기도 한다 $(20,21)$. 이로 인해 된장을 섭취함으로서 유발될 수 있는 성인병을 예방하기 위해서는 된장 중의 식염 함량을 낮추는 것이 시급함에도 불구하고 그동안 된장에 대한 연구는 첨가 한 식염의 농도에 관한 연구보다는 기능성 물질을 첨가한 된장 연구에 관한 소재가 주를 이루었다. 이들 연구에서는 된장에 기능성 물질이나 식품의 첨가와 함께 식염의 농도는 주로 시판되고 있는 된장에서 일반적으로 사용되고 있는 농도인 10 14\%의 식염을 첨가하여 된장을 제조하여 그 된장의 특성을 연구(22)한 것이 대부분으로 식염의 함량이 된장의 숙성에 미치는 영향에 관한 자료는 그 중요도에 비하여 다소 미흡한 실정이다.

본 연구에서는 저염 된장을 제조함에 있어 된장의 맛과 조화를 이루며 유황 화합물의 일종인 alliin이 분해되어 생 성되는 allicin에 기인하여 항균, 항암, 항산화와 같은 인체 의 생리활성을 강화하는 것으로 알려진 $(23,24)$ 마늘을 $10 \%$ 첨가하여 6 12\%의 저염 된장을 제조하고, 숙성기간에 따 른 품질특성을 분석함으로써 마늘을 첨가한 저염 된장 제조 시 적정 식염 첨가량을 설정하고자 하였다.

\section{재료 및 방법}

\section{실험재료}

된장 제조에 사용된 대두는 함양농협(경남 함양군)에서 판매하는 태광품종, 마늘은 새남해농협(경남 남해군), 소금 은 신안에서 생산된 천일염을 구입하였으며, 소맥곡자 (wheat koji)는 몽고식품주식회사(경남 창원시)에서 분양받 아 사용하였다.

\section{발효 균주 선발 및 배양}

마늘 된장의 발효 균주 선발을 위해서 시중에 판매중인 된장으로부터 여러 Bacillus 균주를 분리하였다. 분리 균주 들을 이용하여 $20 \%$ 마늘이 첨가된 청국장을 제조한 후 발효가 잘되면서 이취가 없는 2개의 Bacillus 균주를 선발하 였다. 선발된 균주를 $16 \mathrm{~s} \mathrm{rDNA}$ sequencing을 통해 동정한 결과 Bacillus amyloliquefaciens로 확인되었으며, 각 균주는 $\mathrm{MJ} 1-4, \mathrm{EMD} 17$ 로 명명하였다. 분리된 균주를 이용하여 마 늘된장 제조에 첨가될 청국장을 제조하였다. 청국장은 콩 을 세척하여 상온에서 12 시간 동안 물에 불려 팽윤시켰으 며, $121 \pm 1{ }^{\circ} \mathrm{C}$ 에서 30 분간 증자한 후 상온에서 충분히 식힌
후, B. amyloliquefaciens MJ1-4와 EMD17 균주를 각각 3\%씩 접종하였으며, $37^{\circ} \mathrm{C}$ 배양기에서 72 시간 배양하여 제조하였 다.

효모 역시 시중에 판매되는 된장으로부터 분리하여 선별 하였으며, Pichia farinosa로 동정이 되어 P. farinosa SY80 로 명명하였다. 된장에 첨가될 효모는 YPD 액체배지 (Difco, USA)에 접종한 후 $30^{\circ} \mathrm{C}$ 에서 48 시간 진탕배양하여 준비하였다. 이때 효모의 농도는 $1 \times 10^{8} \log \mathrm{CFU} / \mathrm{g}$ 이었다.

\section{된장 제조}

된장 제조를 위한 재료의 혼합 비율은 몽고식품주식회사 로부터 제 공받았으며, 이를 소규모로 조정하여 Table 1과 같이 염 농도의 비율을 조정하여 사용하였다. 마늘은 분쇄 된 생마늘을 사용하였으며, 첨가농도는 예비실험 및 선행 연구를 통하여 제조된 된장 총량의 $10 \%$ 가 되도록 하였고 소금은 5 12\%로 조절하였다. 불린 콩은 12시간 수침 후, 고압멸균기 $\left(121^{\circ} \mathrm{C}, 40\right.$ 분 $)$ 를 이용하여 증자하였으며, 준비 한 재료를 비율대로 고루 혼합한 후 멸균한 유리병에 담아 상온에서 42 일간 발효시키면서, 7 일 간격으로 시료를 채취 하여 실험에 사용하였다.

Table 1. The mixing ratio of ingredients for the preparation of low salted Doenjang

\begin{tabular}{lcccc}
\hline \multirow{2}{*}{ Ingredients } & \multicolumn{3}{c}{ (g) } \\
\cline { 2 - 5 } & 6 & 8 & 10 & 12 \\
\hline Swelling soybean & 2,000 & 2,000 & 2,000 & 2,000 \\
Wheat koji & 1,080 & 1,080 & 1,080 & 1,080 \\
Cheonggukjang $^{1)}$ & 300 & 300 & 300 & 300 \\
Yeast $^{2}$ & 120 & 120 & 120 & 120 \\
Salt & 300 & 400 & 500 & 600 \\
Water & 700 & 600 & 500 & 400 \\
Garlic & 500 & 500 & 500 & 500 \\
\hline \multicolumn{1}{c}{ Total } & 5000 & 5000 & 5000 & 5000 \\
\hline
\end{tabular}

${ }^{1)}$ Cheongoukjang : fermented using the Bacillus amyloliquefaciens MJ1-4 and EMD17 ${ }^{2}$ Yeast : prepared by inoculating the Pichia farinosa SY80 strain in YPD liquid medium

색 도

된장을 $60 \mathrm{~mm}$ petri dish에 빈 공간이 없도록 담아 색차계 (Ultra Scan VIS, Hunter Associates Laboratory Inc, Reston, $\mathrm{VA}, \mathrm{USA}$ )를 사용하여 5회 반복하여 측정한 후 Hunter scale 에 의해 L(lightness), a(redness), b(yellow) 값으로 표시하였 다. 이 때 사용한 표준백판의 $\mathrm{L}, \mathrm{a}$ 및 b 값은 각각 99.40, -0.13 및 +0.04 였다.

염 도

시료의 염도는 시료 $5 \mathrm{~g}$ 을 칭량하여 증류수 $50 \mathrm{~mL}$ 에 
희석한 후 침출시킨 다음 여과지(No. 2, Advantec Tokyo, Japan)로 여과하여 그 여과액을 이용하여 saltmeter(Atago ES-421, Atago Co., Tokyo, Japan)로 3회 반복 측정한 값에 희석 배수를 곱하여 평균값으로 표시하였다.

\section{$\mathrm{pH}$ 및 산도}

시료의 $\mathrm{pH}$ 와 적정산도는 $\mathrm{G} 20$ compact titrator(METTLER TOLEDO, Switzerland)를 이용하여 측정하였다. 시료 $5 \mathrm{~g}$ 을 취해 증류수 $50 \mathrm{~mL}$ 를 가한 후 잘 용해하여 여과한 후 여과 한 추출물 일정량을 취하여 시료액의 $\mathrm{pH}$ 를 측정하고 적정 산도는 $0.1 \mathrm{~N} \mathrm{NaOH}$ 용액으로 시료액의 $\mathrm{pH}$ 가 8.4가 될 때까 지 적정하고 초산 양으로 환산하였다.

\section{아미노태 질소}

아미노태질소 함량은 Formol 법(25)에 준하여 측정하였 다. 즉, 시료 $5 \mathrm{~g}$ 에 증류수 $50 \mathrm{~mL}$ 를 가하고 교반하여 충분히 용해한 다음 $3,000 \mathrm{rpm}$ 에서 10 분간 원심분리한 상층액을 $20 \mathrm{~mL}$ 을 취하였다. 여기에 $0.1 \mathrm{~N} \mathrm{NaOH}$ 용액을 가해 $\mathrm{pH}$ 8.4 로 조정한 후, $20 \mathrm{~mL}$ 의 중성 formalin(pH 8.3)을 가하고 다시 $0.1 \mathrm{~N} \mathrm{NaOH}$ 용액으로 $\mathrm{pH} 8.4$ 가 되도록 중화 적정하였 다. 별도로 증류수에 대한 바탕시험을 실시하여 아미노태 질소 함량을 구하였다.

\section{환원당}

환원당의 함량은 dinitrosalicylic acid(DNS)법(26)에 따라 시료 $5 \mathrm{~g}$ 에 증류수 $50 \mathrm{~mL}$ 을 가하여 진탕 혼합한 다음 여과 지(No. 2, Advantec)로 여과한 여액을 20배 희석하여 시료액 으로 하였다. 희석액 $2 \mathrm{~mL}$ 과 DNS 시약 $6 \mathrm{~mL}$ 을 혼합하여 $100^{\circ} \mathrm{C}$ 의 물에서 5 분 동안 중탕한 것을 충분히 식힌 후 spectrometer(Libra S35, Biochrome Ltd., England)를 이용하 여 $550 \mathrm{~nm}$ 에서 흡광도를 측정하였다. 포도당을 표준물질로 하여 작성한 검량곡선으로부터 환원당 함량 $(\mathrm{g} / 100 \mathrm{~g})$ 을 계 산하였다.

\section{생균수 측정}

마늘 된장의 발효기간 동안 B. amyloliquefaciens MJ1-4와 EMD17 혼합균주 및 효모의 생균수를 측정하였다. 시료 $10 \mathrm{~g}$ 을 $0.1 \%$ 펩톤수 $90 \mathrm{~mL}$ 을 가하고 혼탁 시킨 후 이를 10 배씩 희석하였으며, Bacillus 혼합균주의 생균수를 확인 하기 위해서는 TSA 평판배지를 이용하였으며, 효모 생균수 측정의 경우 chloramphenicol $(10 \mu \mathrm{g} / \mathrm{mL})$ 이 첨가된 $\mathrm{YPD}$ 평 판배지에 도말하여 $30^{\circ} \mathrm{C}$ 에서 24 48시간 배양한 후 콜로니 수를 확인하고 희석배수를 곱하여 생균수 $(\mathrm{CFU} / \mathrm{mL})$ 를 측 정하였다.

통계처리

측정값은 각 분석항목에 대하여 3회 반복 측정하였으며, SPSS(SPSS Inc., Chicago, IL, USA) 통계 package를 이용하 여 Duncan's multiple range test를 시행하였다 $(\mathrm{p}<0.05)$.

\section{결과 및 고찰}

\section{색도의 변화}

숙성기간에 따른 염 농도별 마늘된장의 색도 변화를 Hunter's scale에 의한 L, a, b값으로 표시한 결과는 Table

Table 2. Change on Hunter's color value of low salted garlic Doenjang during fermentation

\begin{tabular}{|c|c|c|c|c|c|c|c|c|}
\hline \multirow{2}{*}{ Items } & \multirow{2}{*}{$\underset{(\%)}{\mathrm{NaCl}}$} & \multicolumn{7}{|c|}{ Fermentation periods (week) } \\
\hline & & 0 & 1 & 2 & 3 & 4 & 5 & 6 \\
\hline \multirow{4}{*}{$\mathrm{L}$} & 6 & $62.9 \pm 0.9^{\mathrm{aD}}$ & $62.1 \pm 1.3^{\mathrm{aD}}$ & $60.9 \pm 1.0^{\mathrm{aC}}$ & $59.5 \pm 1.0^{\mathrm{aB}}$ & $58.8 \pm 1.3^{\mathrm{abAB}}$ & $58.4 \pm 1.1^{\mathrm{aA}}$ & $58.1 \pm 0.6^{\mathrm{aA}}$ \\
\hline & 8 & $63.2 \pm 1.5^{\mathrm{aD}}$ & $62.9 \pm 0.7^{\mathrm{aD}}$ & $60.3 \pm 1.1^{\mathrm{aC}}$ & $59.4 \pm 1.3^{\mathrm{aBC}}$ & $58.9 \pm 1.1^{\mathrm{abAB}}$ & $58.2 \pm 1.5^{\mathrm{aA}}$ & $58.3 \pm 0.7^{\mathrm{aAB}}$ \\
\hline & 10 & $62.6 \pm 1.3^{\mathrm{aC}}$ & $61.9 \pm 1.3^{\mathrm{aC}}$ & $60.7 \pm 1.3^{\mathrm{aB}}$ & $59.7 \pm 0.4 \mathrm{aB}$ & $58.0 \pm 1.1^{\mathrm{aA}}$ & $58.3 \pm 1.2^{\mathrm{aA}}$ & $57.8 \pm 0.5^{\mathrm{aA}}$ \\
\hline & 12 & $62.8 \pm 0.8^{\mathrm{aF}}$ & $62.1 \pm 1.2^{\mathrm{aEF}}$ & $61.0 \pm 1.1^{\mathrm{aDE}}$ & $60.4 \pm 1.1^{\mathrm{aCD}}$ & $59.6 \pm 1.0^{\mathrm{bBC}}$ & $58.9 \pm 0.5^{\mathrm{aAB}}$ & $57.9 \pm 2.5^{\mathrm{aA}}$ \\
\hline \multirow{4}{*}{ a } & 6 & $4.2 \pm 0.3^{\mathrm{aA}}$ & $4.5 \pm 0.3^{\mathrm{bAB}}$ & $4.6 \pm 0.3^{\mathrm{abB}}$ & $4.6 \pm 0.2^{\mathrm{aB}}$ & $4.9 \pm 0.4^{2 \mathrm{C}}$ & $4.6 \pm 0.3^{\mathrm{aB}}$ & $4.6 \pm 0.3^{\mathrm{aBC}}$ \\
\hline & 8 & $4.2 \pm 0.5^{\mathrm{aA}}$ & $4.2 \pm 0.3^{\mathrm{aA}}$ & $4.6 \pm 0.4^{\mathrm{bB}}$ & $5.1 \pm 0.3^{\mathrm{bC}}$ & $4.8 \pm 0.3^{a B C}$ & $4.7 \pm 0.4^{\mathrm{aB}}$ & $4.6 \pm 0.3^{\mathrm{aB}}$ \\
\hline & 10 & $4.4 \pm 0.4^{\mathrm{aAB}}$ & $4.3 \pm 0.3^{\mathrm{ab} A B}$ & $4.2 \pm 0.5^{\mathrm{aA}}$ & $4.6 \pm 0.3^{3 \mathrm{~B}}$ & $4.9 \pm 0.2^{\mathrm{aC}}$ & $4.6 \pm 0.3^{\mathrm{aB}}$ & $4.5 \pm 0.2^{a \mathrm{~B}}$ \\
\hline & 12 & $4.1 \pm 0.2^{\mathrm{aA}}$ & $4.5 \pm 0.3^{\mathrm{abABC}}$ & $4.2 \pm 0.4^{\mathrm{abAB}}$ & $4.5 \pm 0.3^{\mathrm{aABC}}$ & $4.6 \pm 0.4^{\mathrm{aC}}$ & $4.5 \pm 0.3^{\mathrm{aBC}}$ & $4.6 \pm 0 .{ }^{6 \mathrm{BC}}$ \\
\hline \multirow{4}{*}{$\mathrm{b}$} & 6 & $17.3 \pm 0.4^{\mathrm{aA}}$ & $17.3 \pm 1.1^{\mathrm{aA}}$ & $17.5 \pm 0.6^{\mathrm{bA}}$ & $17.4 \pm 0 .{ }^{3 \mathrm{aA}}$ & $18.4 \pm 0.9^{\mathrm{aB}}$ & $17.1 \pm 0.5^{\mathrm{aA}}$ & $17.4 \pm 0.6^{\mathrm{aA}}$ \\
\hline & 8 & $17.5 \pm 0.5^{\mathrm{abA}}$ & $17.6 \pm 0.6^{\mathrm{aA}}$ & $17.6 \pm 0.5^{\mathrm{bA}}$ & $17.9 \pm 0.5^{\mathrm{bA}}$ & $17.8 \pm 0.7^{\mathrm{aA}}$ & $17.7 \pm 0.6^{\mathrm{abA}}$ & $17.4 \pm 0.7^{\mathrm{aA}}$ \\
\hline & 10 & $17.9 \pm 0.4^{\mathrm{bCD}}$ & $17.5 \pm 0.7^{\mathrm{aBC}}$ & $16.8 \pm 0.5^{\mathrm{aA}}$ & $17.3 \pm 0.6^{\mathrm{aABC}}$ & $18.3 \pm 1.0^{\mathrm{aD}}$ & $17.8 \pm 0.5^{\mathrm{bCD}}$ & $17.1 \pm 0.3^{\mathrm{aCD}}$ \\
\hline & 12 & $17.6 \pm 0.8^{\mathrm{abB}}$ & $18.4 \pm 0.5^{\mathrm{bC}}$ & $17.4 \pm 0.5^{\mathrm{bAB}}$ & $17.5 \pm 0.6^{\mathrm{abB}}$ & $18.4 \pm 0.4^{\mathrm{aC}}$ & $17.3 \pm 0.9^{\mathrm{abAB}}$ & $16.8 \pm 1.3^{\mathrm{aA}}$ \\
\hline
\end{tabular}

Each value represents mean $\pm \mathrm{SD}(\mathrm{n}=5)$

${ }^{a-b}$ Means with different in the same column are significantly different at $p<0.05$

${ }^{\mathrm{AF}}$ Means with different superscript in the same row are significantly different at $\mathrm{p}<0.05$. 
2와 같다. 된장의 명도를 나타내는 L(lightness) 값은 염농도 에 따른 통계적인 유의차는 없었으나, 제조 직후 62.6 63.2 의 범위이던 것이 숙성 6주 후에는 57.8 58.3으로 숙성기간 이 경과함에 따라 점차 낮아졌다. 적색도를 나타내는 $\mathrm{a}$ (redness) 값의 경우 숙성 2주 이후부터 증가하는 경향을 보여, 숙성 4주에 4.6 4.9의 범위로 유의적으로 높았으나 이후부터는 다시 감소하는 경향을 나타내었다. 황색도를 나타내는 $\mathrm{b}$ (yellowness) 값은 식염농도 $6 \%$ 와 $8 \%$ 첨가군에 서는 숙성기간에 따른 통계적인 차이가 없었고, $10 \%$ 와 $12 \%$ 식염군에서는 숙성기간의 경과와 더불어 불규칙한 증감을 나타내었으나 전체적으로 식염농도의 차이에 따른 유의차는 미미하였다.

재래된장의 발효 초기 $\mathrm{L}$ 값은 $55.40, \mathrm{a}$ 값은 $4.63, \mathrm{~b}$ 값은 21.79 이던 것이 발효 60 일 후에는 $\mathrm{L}$ 값 39.57 , a값 12.57 , $\mathrm{b}$ 값 22.99로 변화하였다는 Kim과 Rhyu(27)의 결과와 비교 하여 볼 때 $\mathrm{L}$ 값은 감소하고, $\mathrm{b}$ 값은 대차를 나타내지 않아 동일한 경향이었으나 $\mathrm{a}$ 값은 다소 차이가 있었다. 된장의 숙성 중 적색도의 증가와 관련하여 Chang 등(28)은 된장의 갈변이 진행되면서 붉은색 역시 증가하는 것으로 보고한바
있는데, 본 실험의 결과에서는 마늘이 된장의 갈변을 억제 함으로써 적색도의 변화가 적은 것으로 추정된다.

된장 색의 변화는 착색 및 변색으로 구분하기도 하고 효소적 갈변 및 비효소적 갈변으로 구분하기도 하는데(28), 된장은 간장과 같이 가열과정이 없으므로 효소적 갈변이 비효소적 갈변보다 더 크게 작용하는 것으로 보고되어 있다 $(29,30)$. 효소적 갈변의 경우 된장 속의 tyrosine이 여러 단계 의 반응을 거치면서 tyrosinase에 의해 갈색물질인 melanoids 를 형성하면서 발생하는 것으로 알려져 있다(28). 된장의 비효소적 갈변은 저장하는 과정에서 지질분해 및 중합반응 에 의한 것과 아미노 화합물과 환원당과의 반응 등에 의해 생성되는 갈변물질에 의한 것으로 보고되어 있다(28). 된장 의 저장 중 이러한 갈변반응에 의한 변색은 불가피하므로 된장의 색도는 향미와 더불어 관능적 특성에 상당한 영향을 미치며, 특히 소비자에 있어서는 중요한 품질평가 기준이 된다(31). 본 연구 결과에서와 같이 색의 변화가 크기 않은 된장의 제조 및 숙성 조건은 된장의 품질을 향상시키는데 기여할 것으로 생각된다.

Table 3. Change on salinity of low salted garlic Doenjang during fermentation

$(\%)$

\begin{tabular}{cccccccc}
\hline \multirow{2}{*}{$\mathrm{NaCl}(\%)$} & \multicolumn{7}{c}{ Fermentation periods (week) } \\
\cline { 2 - 7 } & 0 & 1 & 2 & 3 & 4 & 5 & 6 \\
\hline 6 & $3.23 \pm 0.21^{\mathrm{aA}}$ & $3.53 \pm 0.06^{\mathrm{aB}}$ & $3.60 \pm 0.00^{\mathrm{aB}}$ & $3.80 \pm 0.00^{\mathrm{aC}}$ & $3.87 \pm 0.06^{\mathrm{aC}}$ & $3.80 \pm 0.10^{\mathrm{aC}}$ & $4.07 \pm 0.06^{\mathrm{aD}}$ \\
8 & $4.23 \pm 0.06^{6 \mathrm{~B}}$ & $3.93 \pm 0.06^{\mathrm{bA}}$ & $4.47 \pm 0.06^{\mathrm{bC}}$ & $4.50 \pm 0.00^{\mathrm{bC}}$ & $4.40 \pm 0.17^{\mathrm{bC}}$ & $4.70 \pm 0.10^{\mathrm{bD}}$ & $4.37 \pm 0.06^{\mathrm{BBC}}$ \\
10 & $4.37 \pm 0.06^{\mathrm{bA}}$ & $5.37 \pm 0.06^{\mathrm{CB}}$ & $5.33 \pm 0.12^{\mathrm{cB}}$ & $5.50 \pm 0.10^{\mathrm{cB}}$ & $5.73 \pm 0.06^{\mathrm{CC}}$ & $5.50 \pm 0.10^{\mathrm{cB}}$ & $5.80 \pm 0.17^{\mathrm{cC}}$ \\
12 & $5.87 \pm 0.15^{\mathrm{cB}^{\mathrm{BB}}}$ & $5.40 \pm 0.00^{\mathrm{CA}}$ & $5.80 \pm 0.10^{\mathrm{dB}}$ & $6.10 \pm 0.10^{\mathrm{dC}}$ & $6.80 \pm 0.10^{\mathrm{dD}}$ & $6.20 \pm 0.10^{\mathrm{dC}}$ & $6.80 \pm 0.00^{\mathrm{dD}}$ \\
\hline
\end{tabular}

Each value represents mean $\pm \mathrm{SD}(\mathrm{n}=3)$

${ }_{a-b}$ Means with different in the same column are significantly different at $p<0.05$.

${ }^{\mathrm{AF}}$ Means with different superscript in the same row are significantly different at $\mathrm{p}<0.05$.

Table 4. Change on $\mathrm{pH}$ and acid level of low salted garlic Doenjang during fermentation

\begin{tabular}{|c|c|c|c|c|c|c|c|c|}
\hline \multirow{2}{*}{ Items } & \multirow{2}{*}{$\begin{array}{c}\mathrm{NaCl} \\
(\%)\end{array}$} & \multicolumn{7}{|c|}{ Fermentation periods (week) } \\
\hline & & 0 & 1 & 2 & 3 & 4 & 5 & 6 \\
\hline \multirow{4}{*}{$\mathrm{pH}$} & 6 & $7.58 \pm 0.03^{\mathrm{aF}}$ & $7.22 \pm 0.02^{\mathrm{aE}}$ & $7.06 \pm 0.02^{\mathrm{aD}}$ & $6.96 \pm 0.01^{\mathrm{aC}}$ & $6.88 \pm 0.02^{\mathrm{aB}}$ & $6.88 \pm 0.01^{\mathrm{aB}}$ & $6.77 \pm 0.02^{\mathrm{aA}}$ \\
\hline & 8 & $7.61 \pm 0.01^{\mathrm{aE}}$ & $7.28 \pm 0.02^{\mathrm{bD}}$ & $7.10 \pm 0.03^{\mathrm{bC}}$ & $6.94 \pm 0.06^{\mathrm{abB}}$ & $6.91 \pm 0.01^{\mathrm{aAB}}$ & $6.91 \pm 0.01^{\mathrm{bAB}}$ & $6.88 \pm 0.01^{\mathrm{bA}}$ \\
\hline & 10 & $7.59 \pm 0.02^{\mathrm{aF}}$ & $7.35 \pm 0.01^{\mathrm{cE}}$ & $7.15 \pm 0.01^{\mathrm{CD}}$ & $7.00 \pm 0.02^{\mathrm{bC}}$ & $6.93 \pm 0.01^{\mathrm{aB}}$ & $6.95 \pm 0.02^{\mathrm{cB}}$ & $6.90 \pm 0.00^{\mathrm{bA}}$ \\
\hline & 12 & $7.60 \pm 0.01^{\mathrm{aF}}$ & $7.39 \pm 0.00^{\mathbb{d E}}$ & $7.19 \pm 0.01^{\mathrm{dD}}$ & $7.09 \pm 0.01^{\mathrm{CC}}$ & $6.99 \pm 0.04^{\mathrm{bB}}$ & $7.00 \pm 0.01^{\mathrm{AB}}$ & $6.91 \pm 0.06^{\mathrm{bA}}$ \\
\hline \multirow{4}{*}{$\begin{array}{l}\text { Acid } \\
(\%)\end{array}$} & 6 & $0.085 \pm 0.001^{\mathrm{bA}}$ & $0.113 \pm 0.004^{c^{B}}$ & $0.126 \pm 0.002^{\mathrm{dC}}$ & $0.131 \pm 0.003^{\mathrm{bD}}$ & $0.137 \pm 0.005^{\mathrm{bE}}$ & $0.138 \pm 0.001^{\mathrm{bE}}$ & $0.149 \pm 0.002^{\mathrm{ch}}$ \\
\hline & 8 & $0.077 \pm 0.002^{\mathrm{aA}}$ & $0.102 \pm 0.005^{\mathrm{bB}}$ & $0.121 \pm 0.003^{\mathrm{cC}}$ & $0.126 \pm 0.007^{\mathrm{bC}}$ & $0.127 \pm 0.003^{\mathrm{aC}}$ & $0.134 \pm 0.003^{\mathrm{abD}}$ & $0.138 \pm 0.002^{\mathrm{bD}}$ \\
\hline & 10 & $0.077 \pm 0.002^{\mathrm{aA}}$ & $0.101 \pm 0.008^{\mathrm{abB}}$ & $0.116 \pm 0.002^{\mathrm{bC}}$ & $0.123 \pm 0.006^{\mathrm{abC}}$ & $0.123 \pm 0.005^{\mathrm{aC}}$ & $0.133 \pm 0.004^{\mathrm{ad}}$ & $0.134 \pm 0.001^{\mathrm{aD}}$ \\
\hline & 12 & $0.076 \pm 0.002^{\mathrm{aA}}$ & $0.091 \pm 0.000^{\mathrm{aB}}$ & $0.111 \pm 0.003^{\mathrm{aC}}$ & $0.116 \pm 0.001^{\mathrm{aD}}$ & $0.123 \pm 0.003^{\mathrm{aE}}$ & $0.128 \pm 0.003^{\mathrm{aF}}$ & $0.131 \pm 0.003^{\mathrm{aF}}$ \\
\hline
\end{tabular}

Each value represents mean \pm SD $(n=3)$

${ }^{\mathrm{a}-\mathrm{d}}$ Means with different in the same column are significantly different at $\mathrm{p}<0.05$.

${ }^{\mathrm{A}-\mathrm{F}}$ Means with different superscript in the same row are significantly different at $\mathrm{p}<0.05$. 


\section{염도의 변화}

마늘을 $10 \%$ 첨가하고, 식염 첨가량을 6 12\%로 달리하여 제조한 된장의 숙성기간에 따른 염도를 측정한 결과(Table 3 ), 염도는 숙성기간이 경과할수록 점차 증가하는 경향을 보여 제조 직후 3.23 5.87\% 였으나 숙성 6주 후에는 4.07 6.80\%였다.

$\mathrm{Ku}$ 등(32)이 고추씨 첨가에 따른 된장의 품질 특성의 변화를 알아보기 위하여 된장의 염도를 약 $14 \%$ 로 조정하여 제조하였을 때 염도는 제조 직후 $13.28 ~ 14.05 \%$ 에서 발효가 진행됨에 따라 큰 변화를 보이지 않았다고 밝힌 바 있는데 이는 본 연구의 결과와는 차이가 있다. 그러나 $\mathrm{Kim}$ 등(33)은 발아 대두 및 발아 검정콩으로 제조한 된장의 품질 특성을 측정하였을 때 본 연구와 동일한 경향으로 된장의 염도가 발효기간 중 미량 상승하였다고 보고하였다. 이러한 된장 중의 염 농도는 된장의 품질을 평가하는데 있어 중요한 지표가 되는 아미노태 질소 및 환원당 함량에 영향을 주는 것으로 알려져 있는데, 염 농도가 낮을수록 이들의 함량은 증가하는 것으로 알려져 있다(22).

\section{$\mathrm{pH}$ 및 산도의 변화}

염 농도를 달리하여 제조한 마늘첨가 된장을 숙성시키면 서 그에 따른 추출물의 $\mathrm{pH}$ 및 적정산도의 변화를 측정하였 다(Table 4). 된장의 $\mathrm{pH}$ 는 식염의 첨가농도에 따른 통계적 인 유의차는 없었으며, 숙성기간이 경과함에 따라 유의하 게 감소하였다. Lee와 $\operatorname{Mok}(22)$ 은 8 14\%로 염 농도를 달리 한 된장의 저장기간에 따른 $\mathrm{pH}$ 를 측정한 결과 초기에는 식염의 농도에 따른 차이를 보이지 않았으며, 발효기간이 경과함에 따라 전반적으로 감소하는 경향을 보인다고 하였 는데, 이는 본 연구의 결과와도 유사한 경향이었다.

된장과 같은 발효식품은 일반적으로 숙성과정 중에 $\mathrm{pH}$ 는 저하하고 산도는 증가하는데(15), 식염 농도를 달리하여 제조한 마늘첨가 된장 역시 이와 일치하는 경향으로 숙성기 간이 길어지면서 산도는 통계적으로 증가하여 제조 직후 0.076 0.085\%이던 것이 숙성 6주차에는 0.131 149\% 였다.

이처럼 된장의 숙성과정 중 $\mathrm{pH}$ 는 감소하고 산도가 증가
하는 것은 lactic acid, acetic acid, oxalic acid, succinic acid 등과 같은 지속적으로 생성되는 유기산에 의한 것으로 생각 되는데, Kum과 $\mathrm{Han}(34)$ 은 숙성과정 중의 된장의 $\mathrm{pH}$ 감소 및 산도의 증가는 미생물 대사작용으로 생성되는 유기산의 축적에서 기인된 결과라고 보고하였다. $\mathrm{Ku}$ 등(30)도 고추 씨를 첨가한 된장은 발효기간이 증가함에 따라 적정산도가 증가한다고 보고하였다. $\operatorname{Lim}$ 과 $\operatorname{Song}(35)$ 은 된장의 발효가 진행됨에 따라 산도는 증가하나 숙성 40 일째에서 첨가물 및 염도에 따른 산도는 큰 차이를 보이지 않아 첨가물의 첨가 및 저염화는 신맛에는 거의 영향을 미치지 않는 것으 로 고찰한 바 있다.

\section{환원당 함량의 변화}

Table 5는 저장기간에 따른 염 농도별 마늘된장의 환원당 을 측정한 결과로, 숙성기간이 경과할수록 환원당의 함량 은 유의적으로 증가하였으며, 첨가된 식염농도가 높을수록 환원당의 함량이 더 낮았다. 된장 제조직후 식염을 $6 \%$ 첨가 한 시료의 환원당 함량은 $1.88 \mathrm{~g} / 100 \mathrm{~g}$ 으로 8,10 및 $12 \%$ 염첨가구에 비해 각각 $1.6 \%, 26.6 \%$ 및 $28.7 \%$ 더 높았다. 또한 식염 $6 \%$ 첨가군의 경우 숙성 6주차에 환원당 함량은 $9.13 \mathrm{~g} / 100 \mathrm{~g}$ 으로 제조 직후에 비해 약 4.9배 증가하였고, 식염 $10 \%$ 와 $12 \%$ 첨가군은 각각 $7.94 \mathrm{~g} / 100 \mathrm{~g}$ 및 $7.25 \mathrm{~g} / 100$ $\mathrm{g}$ 으로 절대값은 더 낮았으나 증가폭은 더 커서 5.7배와 5.4 배 씩 증가하였다.

된장 발효시 고지 등 전분질 원료의 분해에 의해 환원당 이 생성되는데, 그 생성속도가 미생물에 의해 이용되는 속 도보다 높으면 총 함량이 증가하므로 된장의 발효 중반까지 는 환원당 함량이 증가하나 발효 후기에는 미생물 생육과 Maillard 반응에 의한 갈변이 계속되면서 생성된 당을 소비 하므로 당의 소비속도가 생성속도를 상회하여 총량은 감소 하는 것으로 알려져 있다(22). 소금으로 된장을 제조하고 30 일간 발효시킨 된장의 환원당 변화를 측정한 $\mathrm{Kim}$ 등(36) 은 발효 10 일까지 환원당의 함량은 급속히 증가하다가 그 이후에는 감소한다고 하였으며, Rho 등(37)은 된장의 환원 당은 발효초기 빠르게 증가하나 발효 20일 이후 큰 변화를

Table 5. Change on reducing sugar content of low salted garlic Doenjang during fermentation

$(\mathrm{g} / 100 \mathrm{~g})$

\begin{tabular}{cccccccc}
\hline \multirow{2}{*}{$\mathrm{NaCl}(\%)$} & \multicolumn{7}{c}{ Fermentation periods (week) } \\
\cline { 2 - 7 } & 0 & 1 & 2 & 3 & 4 & 5 & 6 \\
\hline 6 & $1.88 \pm 0.02^{\mathrm{bA}}$ & $3.42 \pm 0.03^{\mathrm{dB}}$ & $5.13 \pm 0.15^{\mathrm{CC}}$ & $6.22 \pm 0.11^{\mathrm{dD}}$ & $7.51 \pm 0.56^{\mathrm{bF}}$ & $7.39 \pm 0.01^{\mathrm{cE}}$ & $9.13 \pm 0.17^{\mathrm{dG}}$ \\
8 & $1.85 \pm 0.20^{\mathrm{bA}}$ & $3.11 \pm 0.01^{\mathrm{cB}}$ & $5.04 \pm 0.08^{\mathrm{CC}}$ & $5.94 \pm 0.07^{\mathrm{cD}}$ & $6.87 \pm 0.22^{\mathrm{abE}}$ & $7.44 \pm 0.09^{\mathrm{cF}}$ & $8.32 \pm 0.12^{\mathrm{cF}}$ \\
10 & $1.38 \pm 0.01^{\mathrm{aA}}$ & $2.92 \pm 0.00^{\mathrm{bB}}$ & $4.65 \pm 0.07^{\mathrm{bC}}$ & $5.71 \pm 0.04^{\mathrm{bD}}$ & $6.84 \pm 0.66^{\mathrm{abE}}$ & $6.86 \pm 0.04^{\mathrm{bE}}$ & $7.94 \pm 0.10^{\mathrm{bG}}$ \\
12 & $1.34 \pm 0.01^{\mathrm{aA}}$ & $2.27 \pm 0.01^{\mathrm{aB}}$ & $3.94 \pm 0.01^{\mathrm{aC}}$ & $4.97 \pm 0.07^{\mathrm{aD}}$ & $6.32 \pm 0.07^{\mathrm{aE}}$ & $6.17 \pm 0.07^{\mathrm{aE}}$ & $7.25 \pm 0.05^{\mathrm{aF}}$ \\
\hline
\end{tabular}

Each value represents mean \pm SD ( $n=3$ )

${ }^{\mathrm{a}-\mathrm{b}}$ Means with different in the same column are significantly different at $\mathrm{p}<0.05$

${ }^{\mathrm{A}-\mathrm{F}}$ Means with different superscript in the same row are significantly different at $\mathrm{p}<0.05$. 
보이지 않다가 45 일부터는 점차 감소한다고 보고하였다. 이들의 연구결과와 본 연구의 결과를 비교할 때 숙성 6주까 지 환원당의 생성이 증가한 것은 첨가된 마늘에 의해 발효 속도가 조절되면서 당의 소비가 서서히 일어났기 때문으로 추정된다.

\section{아미노태 질소 함량의 변화}

아미노태 질소는 아미노산에서 유리아미노기로 존재하 는 질소의 화학형태의 것을 말하며, 아미노기 말단을 갖는 화합물의 총량을 가리키는 식품의 품질지표항목으로 쓰이 고 있는데, 된장의 제조와 숙성 과정 중에 콩 단백질이 효소 작용으로 가수분해되어 맛을 내는 아미노산을 형성하게 되는데 일반적으로 이 함량이 높은 장류가 성분면에서도 좋게 평가받고 있다(31).

식염의 농도를 달리하여 제조된 마늘된장의 아미노태 질소(Table 6)는 식염 농도가 증가할수록 함량이 낮았으며, 숙성기간이 길어질수록 유의하게 증가하였다. 즉, 된장 제 조 직후 식염 $6 \%$ 첨가군의 아미노태 질소 함량은 114.35 $\mathrm{mg} \%$ 였으나 식염을 $12 \%$ 첨가한 군에서는 $101.96 \mathrm{mg} \%$ 로 그 함량이 더 낮았는데, 숙성기간의 경과와 더불어 그 값이 점차 증가하여 6주 후에는 각각 $287.39 \mathrm{mg} \%$ 와 $212.63 \mathrm{mg} \%$ 로 통계적인 유의차를 보였다.

저염 된장의 발효 중 아미노태 질소 함량은 된장의 염 농도가 낮을수록 높았으며, 발효기간에 따라 지속적으로 증가한다는 보고된 바 있는데(22), 이는 본 연구의 결과와도 일치하였다. Mok 등(38)은 염농도가 낮은 된장에서 아미노 태 질소 함량이 높게 나타난 것은 프로테아제 등 단백질 분해에 관여하는 효소의 활성이 더 높기 때문이라고 고찰한 바 있다. 더덕 분말(39)과 생마 및 마 분말(17)을 첨가한 된장을 일반된장과 비교하였을 때 아미노태 질소의 생성이 높게 나타난다는 연구보고가 있지만 매실분말을 첨가한 된장의 경우에는 매실분말의 첨가로 인하여 된장의 $\mathrm{pH}$ 가 낮아지고 이로 인해 프로테아제의 작용 또한 저해되어 일반 된장보다 아미노태 질소의 함량이 더 낮았다는 보고(40)도
있어 첨가되는 부재료가 아미노태 질소의 함량에 영향을 미침을 알 수 있다. 본 연구의 결과에서도 아미노태 질소함 량의 최고치는 $290 \mathrm{mg} \%$ 으로 일반적인 대두된장의 평균 아미노태 질소 함량인 250 430 $\mathrm{mg} \%$ 의 범위(39)에 비해

A) Bacilli (log CFU/g)

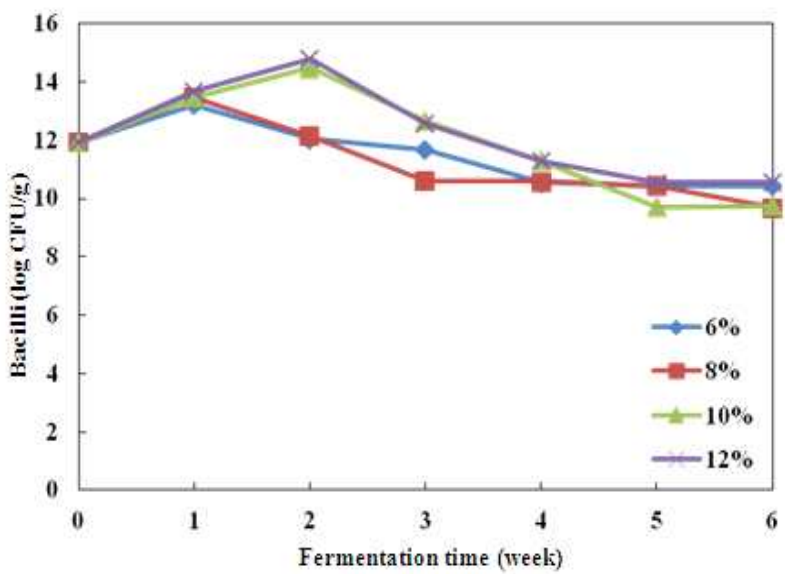

B) Yeast $(\log \mathrm{CFU} / \mathrm{g})$

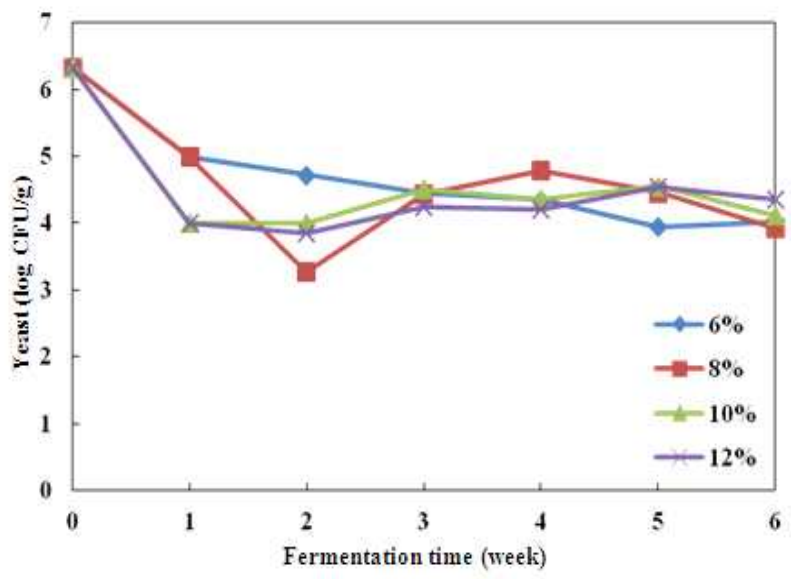

Fig. 1. Changes in viable cell, Bacillus (A) and yeast (B) during fermentation of different Doenjang for 6 weeks.

Table 6. Change on amino nitrogen content of low salted garlic Doenjang during fermentation

$(\mathrm{mg} \%)$

\begin{tabular}{cccccccc}
\hline \multirow{2}{*}{$\mathrm{NaCl}(\%)$} & \multicolumn{7}{c}{ Fermentation periods (week) } \\
\cline { 2 - 8 } & 0 & 1 & 2 & 3 & 4 & 5 & 6 \\
\hline 6 & $114.35 \pm 13.11^{\mathrm{abA}}$ & $165.59 \pm 9.20^{\mathrm{cB}}$ & $205.14 \pm 3.51^{\mathrm{CC}}$ & $209.46 \pm 26.24^{\mathrm{bC}}$ & $248.84 \pm 6.98^{\mathrm{cD}}$ & $274.00 \pm 3.03^{\mathrm{CE}}$ & $287.39 \pm 10.74^{\mathrm{dE}}$ \\
8 & $127.32 \pm 8.26^{\mathrm{bA}}$ & $146.52 \pm 11.97^{\mathrm{bCA}}$ & $196.63 \pm 30.61^{\mathrm{cB}}$ & $187.87 \pm 7.66^{\mathrm{bB}}$ & $241.01 \pm 12.42^{\mathrm{CC}}$ & $230.14 \pm 15.37^{\mathrm{bC}}$ & $253.38 \pm 2.44^{\mathrm{cC}}$ \\
10 & $121.11 \pm 8.78^{\mathrm{abA}}$ & $124.72 \pm 14.59^{\mathrm{aA}}$ & $158.91 \pm 8.01^{\mathrm{bB}}$ & $156.79 \pm 8.17^{\mathrm{aB}}$ & $204.19 \pm 9.27^{\mathrm{bC}}$ & $214.06 \pm 15.30^{\mathrm{bCD}}$ & $231.96 \pm 7.71^{\mathrm{bD}}$ \\
12 & $101.96 \pm 12.15^{\mathrm{aA}}$ & $129.42 \pm 2.96^{\mathrm{abB}}$ & $117.28 \pm 13.14^{\mathrm{aAB}}$ & $145.80 \pm 11.07^{\mathrm{aC}}$ & $181.05 \pm 9.28^{\mathrm{aD}}$ & $188.36 \pm 5.95^{\mathrm{aD}}$ & $212.63 \pm 2.78^{\mathrm{aE}}$ \\
\hline
\end{tabular}

Each value represents mean \pm SD $(n=3)$

${ }^{\mathrm{a}-\mathrm{b}} \mathrm{M}$ Means with different in the same column are significantly different at $\mathrm{p}<0.05$.

${ }^{\mathrm{A}-\mathrm{F}}$ Means with different superscript in the same row are significantly different at $\mathrm{p}<0.05$. 
낮았는데, 이는 부재료로 첨가된 마늘이 프로테아제의 작 용에 영향을 미치기 때문인 것으로 판단된다.

\section{미생물의 변화}

마늘을 $10 \%$ 첨가하고, 식염 농도를 달리하여 제조한 마 늘 첨가 된장의 숙성기간 중 7일 간격으로 생균수를 측정한 결과는 Fig. 1과 같다. 숙성기간 동안 Bacillus 균주의 생육곡 선은 발효 초기인 숙성 1 2주까지는 증가하였으나 발효가 진행될수록 완만하게 감소하는 경향을 나타내었다(A). 반 면에 효모는 된장의 발효기간 동안 점차 감소하는 경향을 나타내었는데, 숙성 1 주에 가장 감소폭이 컸는데, 식염의 농도가 높을수록 효모의 수는 더 많이 감소하였다(B). 숙성 2 주까지는 염농도에 따른 효모의 생육정도에 차이가 컸으 나 숙성 3 주부터는 대차 없이 불규칙한 미량의 증감을 보였다.

Mok 등(41)은 $8,10,12,14 \%$ 의 염을 첨가하여 제조한 된장은 염 농도에 따라 미생물의 수에 차이를 보이는데, 염도가 낮은 시료일수록 세균, 곰팡이 및 효모가 감소하였 다고 하였다. Jang 등(42)이 인삼 농축액을 첨가한 재래식 된장의 발효과정 중 균수를 측정한 결과에서는 발효 45 일 까지는 균수가 증가하다가 그 이후에는 감소하였는데, 인 삼 농축액 첨가군의 경우 대조군과 비교하여 총 균수가 낮았다고 보고하였다.

메주의 발효에 관여하는 Bacillus는 주로 가수분해 효소 를 생산하여 영양물질을 분해하는 역할을 하는데, 염이 첨 가되는 된장의 발효과정에는 활성이 미미한 것으로 알려져 있다(43). 효모에 의한 된장의 숙성은 풍미와 품질을 결정하 는 중요한 요인이나 지나치게 높은 효모수는 이상발효를 일으키고 가스를 발생시켜 된장제품의 포장 및 유통에서 악영향을 미치기도 한다(41). 본 연구의 결과 숙성 초기에 Bacillus의 생육은 촉진된 반면 효모의 생육은 억제되었고, 숙성 3주부터는 이들 모두 일정 수준의 생육정도를 유지하 고 있어 저염된장 제조시 마늘의 첨가는 발효에 유리한 Bacillus의 생육은 유지하되, 이상발효는 억제시키고, 적절 한 발효속도를 유지하는데 기여하는 것으로 판단된다.

\section{요 약}

분쇄한 생마늘 $10 \%$ 와 식염을 $6,8,10$ 및 $12 \%$ 로 달리하여 저염 마늘 된장을 제조하고, 상온에서 6주간 숙성시키면서 일주일 간격으로 시료를 취하여 숙성기간에 따른 품질 특성 의 변화를 분석하였다. 숙성 시간이 경과할수록 명도는 감 소하였으나, 적색도와 황색도는 유의적인 변화의 경향이 없었다. 염도는 된장 제조 직후에 비해 숙성 6주차에 $1 \%$ 정도씩 증가하였으며, $\mathrm{pH}$ 는 저장기간이 경과할수록 점차 감소하였으며, 산도는 이와 상반되게 증가되는 경향이었
다. 환원당은 숙성기간의 경과와 더불어 유의적으로 증가 하여 된장 제조 직후에 $1.34 \sim 1.88 \mathrm{~g} / 100 \mathrm{~g}$ 이던 것이 숙성 6주차에는 7.25 9.13 g/100 g으로 변화하였는데, 식염의 첨 가 농도가 낮을수록 환원당의 함량이 더 높았다. 아미노태 질소는 100 130 mg\%에서 숙성 6주차에는 210 290 mg\%로 약 2 배 증가하였는데, 식염의 첨가 농도가 높을수록 아미노 태질소의 함량은 더 낮았다. 된장의 발효 균주인 Bacillus 균주의 생육은 숙성 14 일까지 증가되다가 그 이후부터는 감소되는 경향이었는데, 식염 $10 \%$ 와 $12 \%$ 첨가군에서는 숙성 14일까지 Bacillus 균주의 생육이 양호하였다. 반면 효모는 된장의 숙성 초기에 급격히 감소하였으며, 숙성 21 일 이후에는 일정범위를 유지하여 큰 변화는 없었다. 이상 의 결과를 종합하여 볼 때 마늘이 첨가된 저염 된장은 염 농도가 낮을수록 환원당이나 아미노태 질소의 함량이 더 높았고, 이화학적인 품질에도 크게 영향을 받지 않아 $6 \%$ 정도의 식염첨가로 저염화가 가능할 것으로 확인되었다.

\section{감사의 글}

본 연구는 농림축산식품부의 고부가가치식품기술개발 사업(과제번호 : 112066031)의 지원에 의해 이루어진 것입 니다.

\section{References}

1. Park SK, Seo KI, Shon MY, Moon JS, Lee YH (2000) Quality characteristics of home-made Doenjang, a traditional Korean soybean paste. Korean J Food Cookery Sci, 16, 121-127

2. Park KY, Hwang KM, Jung KO, Lee KB (2002) Studies on the standardization of Doenjang (Korean soybean paste) 1. Standardization of manufacturing method of Doenjang by literatures. J Korean Soc Food Sci Nutr, 31, 343-350

3. Lim SY, Park KY, Rhee SH (1999) Anticancer effect of doenjang in vitro sulforhodamine B (SRB) assay. Korean Soc Food Sci Nutr, 28, 240-245

4. Lim SY (2004) Inhibitory effect of methanol extract of doenjang on growth and DNA synthesis of human cancer cells. J Korean Chem Soc, 33, 936-940

5. Rhee CH, Kim WC, Rhee IK, Park HD (2008) Effects of inoculation of Bacillus subtilis cells on the fermentation of Korea traditional soy paste. J Korean Chem Soc, 15, 598-605

6. Santiago LA, Hiramatsu H, Mori A (1992) Japanese 
soybean paste miso scavengy free radicals and inhibit lipid peroxidation. J Nutr Sci Vitaminol, 38, 297-302

7. Lee HT, Kim JH, Lee SS (2009) Comparison of biological activity between soybean pastes adding sword bean and general soybean pastes. J Fd Hyg Safety, 24, 94-101

8. Lee IK, Kim JK (2002) Effects of dietary supplementation of Korean soybean paste (Doenjang) on the lipid metabolism in rats fed a high fat and/or a high cholesterol diet. J Korean Public Health Assoc, 28, 282-305

9. Kim MJ, Rhee HS (1990) Studies on the changes of taste compounds during soy paste fermentation. Korean J Soc Food Sci, 6, 1-8

10. Shin ZI, Ahn CW, Nam HS, Lee HJ, Moon TH (1995) Fractionation of angiotensin converting enzyme (ACE) inhibitory peptides from soybean paste. Korean J Food Sci Technol, 27, 230-234

11. Hwang JH (1997) Angiotensin I converting enzyme inhibitory effect of doenjang fermented by $B$. subtilis isolated from meju, Korean traditional food. J Korean Soc Food Sci Nutr, 26, 775-783

12. Kim SH (1998) New trend of studying on potential activities of Doenjang -fibrinolytic activity. Korea Soybean Digest, 15, 8-15

13. Lee SK, Heo S, Ju HK, Song KB (1999) The study on isolation of fibrinolytic bacteria from soybean paste. J Korean Soc Agric Chem Biotechnol, 42, 6-11

14. Lee BK, Jang YS, Yi SY, Chung KS, Choi SY (1997) Immunomodulators extracted from Korean-style fermented soybean paste and their function. 1. Isolation of B cell mitogen from Korean style fermented soybean paste. Korean J Immunol, 19, 559-569

15. Choi SY, Sung NJ, Kim HJ (2006) Physicochemical characteristics of traditional with added Lentinus edodes. Korean J Soc Food Cookery Sci, 22, 69-79

16. Kim JH, Oh HJ, Oh YS, Lim SB (2010) The quality properties composition of post-daged Doenjang (fermented soybean pastes) added with citrus Fruits, green tea and cactus powder. J East Asian Soc Dietary Life, 20, 279-290

17. Jun HI, Song GS (2012) Quality characterisitcs of Doenjang Added with Yam (Dioscorea batatas). J Agri Life Sci, 43, 54-58

18. Bae JO, Lee KJ, Park JS, Choi DS (2012) Preperation of sweet potato Doenjang using colored sweet potato. Korean J Food Nutr, 25, 529-537

19. Mok CK, Song KT, Lee JY, Park YS, Lim SB. (2005) Change in microorganism and enzyme activity of low salt soybean paste (Doenjang) during fermentation. Food Eng Prog, 9, 112-117

20. Kim JD, Choe M, Ju JS (1995) A study on correlation between blood pressure and dietary $\mathrm{Na}, \mathrm{K}$ intakes pattern in the family members of normal and cerebrovascular disease patients. J Korean Soc Food Nutr, 24, 24-29

21. Park BJ, Jang KS, Kim DH, Yook HS, Byun MW (2002) Changes of microbiological and physicochemical characteristics of Doenjang prepared with low salt content and gamma irradiation. Korean J Food Sci Technol, 34, 79-84

22. Lee JY, Mok CK (2010) Change in physicichemical properties of low salt soybean paste (Doenjang) during fermentation. Food Eng Prog, 14, 153-158

23. Nishimura H, Hanny W, Mizutani J (1988) Volatile flavor components and antithrombotic agent. J Agric Food Chem, 36, 563-569

24. Watanabe $\mathrm{T}$ (1988) Utilization of principles of garlic Food Processing, 23, 40-42

25. Lee GY. Kim HS, Lee HG, Han O, Chang UT (1997) Studies on the prediction of the shelf-life of Kochujang through the physicochemical and sensory analysis during storage. J Korean Soc Food Sci Nutr, 26, 588-594.

26. Miller GL (1959) Use of dinitrosalicylic acid reagent for determination of reducing sugar. Anal Chem, 31, 426-431

27. Kim EY, Rhyu MR (2000) The chemical properties of Doenjang prepared by Monascus koji. Korean J Food Sci Technol 32, 1114-1121

28. Chang M, Kim IC, Chang HC (2010) Effect of solar Salt on the quality characteristics of Doenjang. J Korean Soc Food Sci Nutr, 39, 116-124

29. Kwon DJ, Kim YJ, Kim HJ, Hong SS, Kim HK (1998) Change of color in Doenjang by different browning factors. Korean J Food Sci Technol, 30, 1000-1005

30. Lee SK, Kim ND, Kim HJ, Park, JS (2002) Development of traditional Doenjang improved in color. Korean J Food Sci Technol, 34, 400-406

31. Kim JG (2004) Change of components affecting organoleptic quality during the ripening of traditional korean soybean paste, -amino nitrogen, amino acids, and color-. J Fd Hyg Safety, 19, 31-37

32. Ku KH, Choi EJ, Park WS (2009) Quality characteristics of Doenjang Added with red pepper (Capsicum annuum L.) seed. J Korean Soc Food Sci Nutr, 38, 1587-1594

33. Kim HE, Han SY, Jung JB, Ko JM, Kim YS (2011) Quality characteristics of Doenjang (soybean paste) 
prepared with germinated regular soybean and black soybean. Korean J Food Sci Technol, 43, 361-368

34. Kum JS, Han O (1997) Changes I physicochemical properties of Kochujang and Doenjang prepared with extrudated wheat flour during fermentation. J Korean Soc Food Sci Nutr, 26, 601-605

35. Lim SI, Song SM (2010) Fermentation properties of low-salted Doenjang supplemented with licorice, mustard, and chitosan. Korean J Food Sci Technol, 42, 323-328

36. Kim SH, Kim SJ, Kim BH, Kang SG, Jung ST (2000) Fermentation of Doenjang prepared with sea salts. Korean J Food Sci Technol, 32, 1365-1370

37. Rho JD, Choi SY, Lee SJ (2008) Quality characteristics of soybean pastes prepared using different type of microorganism and mixing ratios. Korean J Food Cookery Sci, 24, 243-250

38. Mok CK, Lee JY, Song KT, Kim SY, Lim SB, Woo GJ (2000) Changes in physicochemical properties of salted and fermented shrimp at different salt levels. Korean J Food Sci Technol, 32, 187-191
39. Hong SC, Choi KS, Lee HJ, Kwon DJ (2010) Effects of Deodeok contents on the qualities of quick fermented Doenjang type product. J Korean Soc Food Sci Nutr, 39, 757-763

40. Park WP, Kim ND, Lee SC, Kim SY, Cho SH (2006) Effects of powder and concentrates of Prnus mume on the quality of Doenjang during fermentation. Korean J Food Preserv, 13, 574-580

41. Mok CK, Song KT, Lee JY, Park YS, Lim SB (2005) Change in microorganisms and enzyme activity of low salt soybean paste (Doenjang) duting fermentation. Food Eng Prog, 9, 112-117

42. Jang SM, Lee JB, An H, Rhee CH, Park HD (2000) Change microorganisms, enzyme activity and physiological functionality in the korean soybean paste with various concentrations ginseng extract during fermentation. Korean J Postharvest Sci Technol, 7, 313-320

43. Lee NS, Oh NS (1996) Characteristics of yeast flora and gas generation during fermentation of Doenjang. Agric Chem Biotech, 39, 255-259

(접수 2014년 5월 13일 수정 2014년 8월 6일 채택 2014년 8월 18일) 